\title{
Application of permeable materials for CBRN protective equipment
}

The new concept of chemical, biological, radiological and nuclear combat clothing offers the opportunity of substantial cost savings by eliminating the need for additional, CBRN overgarments, whose high weight and poor breathability may cause a physiological overload of the soldier. These specific clothing made of filtrosorption material has been designed for modern soldier, increasing his efficiency and reducing total costs. Textile materials embedded in the suit have excellent physical and mechanical properties, air and moisture permeability after climatic treatment and practical usage. During testing of chemical protective overgarment's physiologic suitability the ergometric indicators were determined.

Key words: chemical protection, CBRN clothing, Saratoga ${ }^{T M}$ material, activated charcoal, physiologic suitability

\section{INTRODUCTION}

The concept of the modernization introduced the requirement to equip soldiers with a combat clothing system with fully breathable integral chemical, biological, radiological and nuclear (CBRN) protection. The advantages of such system are: reduced heat stress, reduced weight and bulk of protective equipment to be carried, increased operational efficiency of the soldier in an NBC environment and finally, reduced costs.

Since the World War I, when chemical warfare agents were employed for the first time in large quantities, the protection of soldiers has been an ongoing challenge for research and development personnel. Alongside gas masks that protect against respiratory agents, impermeable rubber suits represented the first body protection. Unfortunately these suits have major drawbacks: they are complicated to don, create high-heat stress for wearers and are vulnerable to unsealed openings and/or damage, so the development of permeable protective suits began in the 1970s. In this type of garment, hazardous gases are removed from the air by means of adsorption conducted by filter fabrics containing activated carbon. Textile filter fabrics of non-woven or polyurethane foam are loaded with activated carbon powder. Other technology use a carbonized and activated woven or knit fabric fixed onto a textile carrier.

Author address: ${ }^{1}$ Military academy, University of Defense, Belgrade, ${ }^{2}$ Innovation Center, Faculty of Chemistry, Belgrade, ${ }^{3}$ Faculty of Technology and Metallurgy, Belgrade, 4Technical Test Center, Belgrade, ${ }^{5}$ Military Technical Institute, Belgrade, ${ }^{6}$ Military academy, University of Defense, Belgrade, Serbia

Paper received: 15. 12. 2014.

Paper accepted: 23. 02. 2015.
The suit consists of a coat and trousers (figure 1 ). The coat features a full-length zippered opening covered by single protective flap, an integrated hood, hook, and pile sleeve closures. The trousers feature adjustable waist tabs, suspenders, and closures on the lower outside section of each leg. The suit can be worn over the duty uniform or undergarments. The suit is wearable in all environments and conditions and is compatible with the gloves, boots and mask. It is not degraded by fresh or salt water and is launderable. The outside layer of material is cotton rip stop that has been corpel treated.

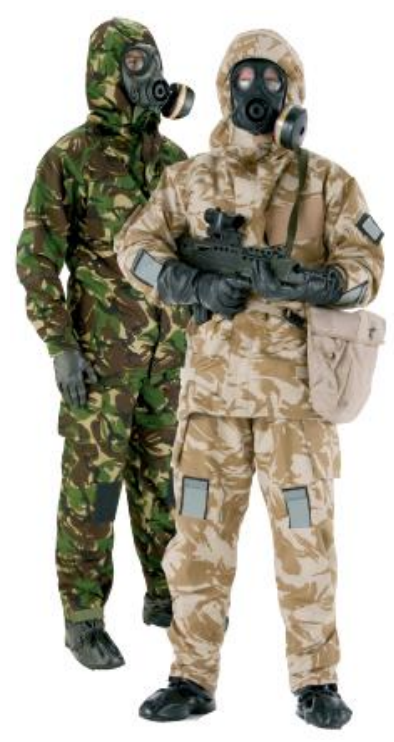

Figure 1 - NBC clothing including Saratoga ${ }^{T M}$ suit

\section{THE CHARACTERISTICS OF TEXTILE PROTECTION MATERIALS}

The Saratoga ${ }^{\mathrm{TM}}$ material has a high flexibility, high air permeability and a low thickness, which together provide very high wearer comfort. The two 
layers and the air gap provide comfort and efficient heat control of the body under all climatic conditions. The suit employs spherical carbon technology to provide effective body protection from well-known chemical/biological warfare agents while offering the best possible flow conditions for body heat dissipation, so that the suit stays as cool as possible. The activated carbon provides additional protection against chemical warfare agents in liquid, vapor and aerosol forms [1].

The latest and most successful technology, developed by Blücher $\mathrm{GmbH} / \mathrm{Germany}$ under the brand name Saratoga ${ }^{\mathrm{TM}}$, offers the highest capacity of adsorption and the best possible comfort under all climatic conditions. Saratoga ${ }^{\mathrm{TM}}$ is based on activated carbon in the form of spherical absorbers that are fixed to a textile carrier fabric.

The capacity to absorb chemical weapon (CW) agents by activated carbon is defined by the characteristics of the porous system, the level of activation and the amount of carbon. Saratoga ${ }^{T M}$ is unique patented composite filter fabric based on highly activated and hard carbon spheres (figure 2.) fixed onto textile carrier fabrics $[2,3]$. With a carbon density of between $180 \mathrm{~g} / \mathrm{m}^{2}$ to $220 \mathrm{~g} / \mathrm{m}^{2}$, the maximum on the market, it provides a minimum of 24 hours protection and at least 45 days of wear under battlefield conditions, including several field washings. Over $85 \%$ of the sphere's outer surface is freely accessible to harmful gases, resulting in an extremely rapid and firm adsorption.

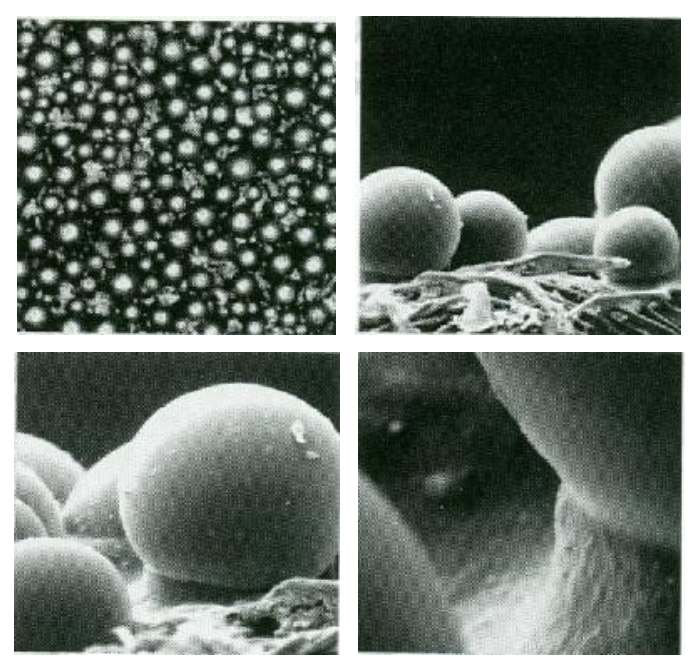

Figure 2 - Active charcoal spheres

The level of activation also is important for desorption (the release of adsorbed gases) because desorption of $\mathrm{CW}$ agents could threaten wearers as well as unprotected personnel. It has been proved that when using carbon beads $\mathrm{CW}$ agents desorbs only above $100{ }^{\circ} \mathrm{C}$ and in concentrations above the non-effect level [3]. Therefore CW agents are trapped safely within the beads.
Rubber suits do not offer any adsorption capacity; they are simply impermeable barriers for CW agents. Semi-permeable membrane materials that have been under research for many years, are airtight, as are rubber suits, but designed to be permeable for water vapor molecules to evaporate from the skin. Unfortunately, the barrier properties of $\mathrm{CW}$ agents make them inferior to rubber. Evaporating water molecules can be absorbed by the membrane for transport to the outside, making the membrane swell to create enough space for larger molecules, such as $\mathrm{CW}$ agents, to pass through.

The lack of adsorptive properties in rubber and membrane suits means that these types of suit have to be completely sealed from the environment. It is almost impossible to avoid damage to a suit during field use and equally impossible to close all openings perfectly because movement in the suit will alter internal pressure and create airflow. Any $\mathrm{CW}$ agent penetrating through openings or even slight damage will be resorbed by the skin from air inside the suit. In Saratoga ${ }^{\mathrm{TM}}$ permeable suits, the adsorptive power of the carbon beads is higher than resorbtion of skin, so the carbon beads remove CW agents from air inside the suit.

Another important criterion is wear comfort or heat stress. Permeable protective clothing was designed so that evaporated sweat may be transported through the filter material and small openings by the air stream created by the wearer's movements. In rubber and membrane suits air stream has to be blocked completely, therefore no transfer of sweat from the inside to the outside takes place because there is no air stream and no transport through the material. The Saratoga ${ }^{\mathrm{TM}}$ system, with its high-capacity carbon beads, offers active sweat management and thus highest wear comfort. Saratoga ${ }^{\mathrm{TM}}$ NBC protective garments can be worn under all climatic conditions with minimal impact on combat effectiveness. The better the wear properties of a protective suit, the longer it can be worn for preventive protection without fear of serious loss to operational strength $[4,5]$.

The microclimate between skin and clothing has a great influence on the wearing properties. The pore structure of the Saratoga ${ }^{\mathrm{TM}}$ spherical absorbers and their hydrophilic properties have the effect that sweat impulses are caught and continuously decomposed. This causes a low increase of humidity and a low atmospheric humidity in the area very close to skin. For that reason Saratoga ${ }^{\mathrm{TM}}$ is pleasant to wear.

The high flexibility of Saratoga ${ }^{\mathrm{TM}}$ filter materials leads to a "pump effect" which increases the microclimate such as a quick exchange of the air in between the inner and outer textile layers. The 
suits are also highly air permeable meaning that sweat and heat stress are reduced [6,7].

\section{TESTING RESULTS}

Saratoga ${ }^{\mathrm{TM}}$ has a very high mechanical stability. Due to excellent mechanical properties, can be used for training purposes; after being washed and packed, the protective suits are fully suitable to be reused. In this investigation ten test subjects were tested in the climatic chamber. The temperature was $30 \stackrel{\circ}{ } \mathrm{C}$, relative humidity $50 \%$. During the 90 minutes, they walked at $5 \mathrm{~km} / \mathrm{h}$. After laboratory testing, we're realized primary missions in the field using this overgarments. The tests are realized in different enviromental conditions.

In several laboratories are tested physical-mechanical, functional characteristics and resistance of materials (inner and outer layer) on influence of high toxic chemical substances. The main characteristics of suit material (inner-filter and outer layer) are given in tables 1 - 3 .

Table 1 - Physical-mechanical textile properties

\begin{tabular}{||c|c|c|c|c||}
\hline \hline \multirow{2}{*}{$\begin{array}{c}\text { Thickness, } \\
\mathrm{mm}\end{array}$} & \multicolumn{2}{c|}{$\begin{array}{c}\text { Before } \\
\text { treatment }\end{array}$} & \multicolumn{2}{c|}{$\begin{array}{c}\text { After climatic } \\
\text { treatment and } \\
\text { use }\end{array}$} \\
\cline { 2 - 5 } & filter & outer & filter & outer \\
\hline Thickness, mm & 0.79 & 0.4 & 0.79 & 0.4 \\
\hline $\begin{array}{l}\text { Breaking } \\
\text { strength, daN }\end{array}$ & 65.3 & 99.4 & 62.7 & 97.4 \\
\hline $\begin{array}{l}\text { Tearing } \\
\text { strength, daN }\end{array}$ & 10.5 & 14.1 & 9.8 & 13.4 \\
\hline \hline
\end{tabular}

Table 2 - Functional properties of textile material (sandwich)

\begin{tabular}{|l|c|c||}
\hline \hline \multicolumn{1}{|c|}{ Thickness, $\mathrm{mm}$} & $\begin{array}{c}\text { Before } \\
\text { treatment }\end{array}$ & $\begin{array}{c}\text { After climatic } \\
\text { treatment and } \\
\text { use }\end{array}$ \\
\cline { 2 - 3 } & filter + outer & filter + outer \\
\hline Air permeability, $\mathrm{Pa}$ & 17.4 & 14.8 \\
\hline $\begin{array}{l}\text { Moisture permeability, } \\
\mathrm{g} / \mathrm{m}^{2} 24 \mathrm{~h}\end{array}$ & 3375 & 3360 \\
\hline
\end{tabular}

Table 3 - Resistance to chemical agents (mustard)

\begin{tabular}{||c|c|c|c|c||}
\hline \hline \multirow{2}{*}{ Sample } & \multicolumn{4}{|c|}{ Penetrated amount, $\mu \mathrm{g} / \mathrm{cm}^{2}$ in 24 hrs } \\
\cline { 2 - 5 } & $\begin{array}{c}1 \mu \mathrm{L} \\
\text { dropsize }\end{array}$ & $\begin{array}{c}1 \mu \mathrm{L} \\
\text { dropsize }\end{array}$ & $\begin{array}{c}1 \mu \mathrm{L} \\
\text { dropsize }\end{array}$ & $\begin{array}{c}2.76 \mu \mathrm{L} \\
\text { dropsize }\end{array}$ \\
\hline 1 & 0.1 & 0.8 & 0.72 & 0.11 \\
\hline 2 & 0.08 & 0.11 & 0.38 & 0.38 \\
\hline 3 & 1.75 & 0.08 & 0.1 & 0.16 \\
\hline 4 & 3.2 & 3.23 & 0.11 & 0.12 \\
\hline 5 & 0.13 & 0.12 & 0.11 & 0.13 \\
\hline 6 & 0.63 & 3.28 & 1.72 & 0.13 \\
\hline \hline
\end{tabular}

\section{CONCLUSION}

A filter material show good results on the Milspec tests, showed in tables 1 - 3 . From the results given in table 1 it can be concluded that textile materials, which are embedded in this suit, have a lower amounts of physical-mechanical properties after climatic treatment and practical use (wearing in different climatic conditions). From the results given in table 2 it can be concluded that these materials have inferior values of air and moisture permeability after climatic treatment and practical use. The laid drop test $(8 \times 1 \mu \mathrm{L})$ using a mustard agent showed a large spread of penetrated amount. From the given characteristics of suit (clothing) material based on Saratoga ${ }^{\mathrm{TM}}$ inner (filter) material, it can be concluded that these materials have excellent mechanical, functional properties and resistance to different chemical agents, which makes that new class of protective clothing are very acceptable and necessary in human and health protection in accident situations, war and terroristic actions with chemical and biological agents. In most of these characteristics, new clothing, including inner Saratoga ${ }^{\mathrm{TM}}$ layer, are much better than old protective clothing based on PUR/textile materials and rubber materials.

\section{LITERATURE}

[1] E. Kissa (1981), Capilary sorption in fibrous assemblies, J. Coll. Interface Sci.,Vol. 83, Issue 1, 1981, pp. 265-272.

[2] R. Karkalić (2006), Optimization of thin layered active charcoal sorption materials embedded into the NBC protective materials in the function of protective characteristics and physiologic compliance, Ph.D. thesis, Military Academy, Belgrade, Serbia.

[3] F. Ellingsen, J. Karlsen (1983), Transport mechanisms through a porous membrane and the subsequent effect on the protection when incorporated into multilayer clothing, Proc. Int. Symp. Protection against Chemical Warfare Agents, Stockholm, Sweden.

[4] J. Mecheels (1991), Korper, Klima-Kleidung, Grundzuge der Bekleidungsphysiologie, Berlin.

[5] K. H. Umbach (1978), Hautphysiologie und Kleidung Bekledungsphysiogiches Institut Hohenstein.

[6] R. Karkalić, R. Popović (2004), Complex performances of the contemporary textile materials covered with active charcoal, The 6th Yugoslav Materials Research Society Conference Yucomat 2004, Herceg Novi, Septrember 13-17, pp. 106-108.

[7] D. Rivin, C. Kendrick (1997), Adsorption properties of vapor-protective fabrics containing activated carbon, Carbon, 35, 1295-1305. 


\section{IZVOD}

\section{PRIMENA FILTROSORPCIONIH MATERIJALA ZA NHB ZAŠTITNU OPREMU}

Novi koncept NHB zaštitne odeće pruža mogućnost velike uštede, eliminišući potrebu za primenu dodatnih NHB zaštitnih sredstava, čija velika masa i loša propustljivost vazduha mogu dovesti do fizioloških preopterećenja vojnika. Ova specijalna zaštitna odeća, izrađena od filtrosorpcionih materijala, je dizajnirana za savremenog vojnika, što mu povećava efikasnost i redukuje ukupne troškove proizvodnje zaštitne odeće. Tekstilni materijali koji su ugrađeni u ovu odeću poseduju dobra fizičko-mehanička svojstava, propustjivi su za vazduh i vodenu paru nakon klimatskih tretmana $i$ tokom praktične upotrebe. Tokom ispitivanja zaštitnih svojstava i karakteristika fiziološke podobnosti određeni su i neki ergometrijski indikatori.

Ključne reči: hemijska zaštita, NHB zaštitna odeća, Saratoga ${ }^{T M}$ materijal, aktivni ugalj, fiziološka podobnost.

Originalni naucni rad

Rad primljen: 15. 12. 2014.

Rad prihvacen: 23. 02. 2015. 